\title{
Centering the Korle Lagoon: exploring blue political ecologies of E-Waste in Ghana
}

\author{
Peter C. Little ${ }^{1}$ \\ Grace A. Akese \\ Rhode Island College, USA \\ Memorial University, Canada
}

\begin{abstract}
Among emerging studies of the global political economy and ecology of electronic waste (or e-waste), few directly explore the already complex waste trades and materialities in relation to the general political ecology of water, flood control, dredging, and neoliberal ecological restoration. Even fewer focus on how this political-ecological challenge is unfolding in a West African context where ocean-based e-waste trades have played a dominant role. This article engages this particular domain of blue economic critique by focusing on Ghana in general and what we shall call "blue political ecologies of e-waste" in particular. The article focuses on e-waste politics unfolding in and around the Korle Lagoon in Accra, Ghana. The Korle Lagoon is an urban marine space of intensive land use, toxic waste disposal, social life, and urban ecological restoration. Amidst heavy contamination, there are attempts to rehabilitate the lagoon through the Korle Lagoon Ecological Restoration Project, an ecological science and restoration project focused on the Lagoon and its river system in the metropolitan area of Accra. It showcases the neoliberal complexities of ecological restoration. Importantly, situated in a multi-use marine environment, the project also highlights, we argue, a political ecological moment that is both about things 'blue', like water quality concerns, but also about other things non-blue such as contestation over land and housing, 'green' international NGO intervention on e-waste risk mitigation, and desires for new urban ecologies. Drawing on ethnographic research conducted between 2015 and 2018, this article contributes to blue political-ecological research and critique in Africa by asking: how do e-waste politics leak into discussions of the blue economy along the Korle Lagoon in Ghana? What are the promises and prospects of a blue political ecology of e-waste in general, and in Africa in particular?
\end{abstract}

Key Words: Political ecology, Ghana, e-waste, lagoon contamination, ecological restoration

\section{Résumé}

Parmi les études émergentes sur l'économie politique et l'écologie mondiales des déchets électroniques, peu explorent directement les métiers et les matérialités déjà complexes liés aux déchets, en relation avec l'écologie politique générale de l'eau, le contrôle des inondations, le dragage et la restauration écologique néolibérale. Moins d'études se concentrent sur la manière dont ce défi politico-écologique se déploie dans un contexte ouest-africain où les métiers des déchets électroniques basés sur l'océan ont joué un rôle dominant. Cet article aborde ce domaine particulier de la critique économique bleue, en se concentrant sur le Ghana en général et sur ce que nous appellerons les «écologies politiques bleues des déchets électroniques» en particulier. L'article se concentre sur la politique en matière de déchets électroniques qui se déroule dans et autour de la lagune de Korle à Accra. La lagune de Korle est un espace marin urbain caractérisé par une utilisation intensive des sols, l'élimination des déchets toxiques, la vie sociale et la restauration écologique urbaine. Dans le contexte de forte contamination, le projet KLER, qui utilise

\footnotetext{
${ }^{1}$ Dr. Peter Little, Associate Professor, Anthropology, Rhode Island College, RI, USA. Email: plittle "at" ric.edu. Grace A. Akese, Department of Geography, Memorial University, Canada. Email: gaa538 "at" mun.ca. Acknowledgements: Thanks to two referees and the JPE editors. Funding came from the Wenner-Gren Foundation for Anthropological Research and a Rhode Island College Faculty Research Grant. This is the sixth article in John Childs and Christina Hicks (eds.). 2019. "Political ecologies of the blue economy in Africa", Special Section of the Journal of Political Ecology 26: 323-465.
} 
des techniques de science écologique et de restauration sur la lagune et son réseau hydrographique dans la métropole d'Accra, tente de réhabiliter la lagune. Il présente les complexités néolibérales de la restauration écologique. Fait important, situé dans un environnement marin à usages multiples, le projet met également en évidence, dit-on, un moment écologique politique qui concerne à la fois les choses «bleues», comme les problèmes de qualité de l'eau, mais aussi d'autres choses «non bleues». Il s'agit notamment des conflits fonciers, de l'intervention d'ONG internationales sur les déchets électroniques, et du désir de nouvelles écologies urbaines. S'appuyant sur des recherches ethnographiques menées entre 2015 et 2018, cet article contribue à la recherche et à la critique politicoécologiques en Afrique en demandant: comment la politique des déchets électroniques entre-t-elle dans les discussions sur l'économie bleue le long de la lagune de Korle au Ghana? Quelles sont les promesses et les perspectives d'une écologie politique bleue des déchets électroniques en general, et de l'Afrique en particulier?

Mots clés: écologie politique, Ghana, déchets électroniques, contamination de la lagune, restauration écologique

\section{Resumen}

De entre los estudios que emergen en economía política global y ecología de desechos electrónicos, unos cuantos exploran los ya complejos intercambios y materialidades con relación a la ecología política del agua, control de inundación, dragado y restauración ecológica neoliberal. Hay aún menos que se enfocan en cómo este reto político y ecológico se desarrolla en un contexto de África occidental donde los intercambios oceánicos de desechos electrónicos han jugado un papel dominante. Este artículo integra este dominio de la crítica económica azul, al enfocarse en Ghana en general y lo que podemos llamar "ecologías políticas azules de desechos electrónicos" en particular. El artículo se enfoca en la política de los desechos electrónicos que se desenvuelve en y alrededor de la laguna Korle en Accra, Ghana. La laguna Korle es un espacio marino urbano con uso de suelo intensivo, disposición de desechos tóxicos, vida social y restauración ecológica urbana. En medio de la grave contaminación hay intentos de rehabilitar la laguna a través del Proyecto de Restauración Ecológica de la Laguna Korle, una iniciativa ecológica de ciencia y restauración enfocada en la laguna y su sistema fluvial en el área metropolitana de Accra. En este, se exhiben las complejidades neoliberales de la restauración ecológica. Consideramos clave que, situado en un ambiente marino de varios usos, el proyecto también destaca en un momento ecológico y político que tiene que ver con cosas "azules": por un lado, asuntos de calidad del agua, y por otro, diversos temas como oposiciones en temas de tierra y vivienda, intervención "verde" de organizaciones en mitigación de riesgo por desechos electrónicos, y el deseo de nuevas ecologías urbanas. Con base en etnografía realizada entre 2015 y 2018, este artículo contribuye a la investigación político-ecológica y a la crítica en África con las preguntas: ¿cómo lo político respecto a desechos electrónicos se infiltra en discusiones de la economía azul a lo largo de la laguna Korle, en Ghana? ¿cuáles son las promesas y las perspectivas de una ecología política azul de los desechos electrónicos en general, y en África en particular?

Palabras clave: ecología política, Ghana, desechos electrónicos, contaminación de laguna, restauración ecológica

\section{Introduction}

One of the most exciting and promising dimensions of political ecology as a field of theory and practice is its continued fascination with relational and boundary thinking in diverse contexts, made up of assemblages of infrastructure, knowledge, narrative, and power. This focus is also a concern of emerging discard studies in general ${ }^{2}$ and those exploring global trades and socio-environmental politics of electronic waste (or e-waste) in particular. ${ }^{3}$ Ewaste is currently an expanding trade sector of the global economy. The UN, for example, has claimed this sector generated nearly \$US18 billion in 2017, with growth on the upswing according to a recent World Bank report (Kaza et al. 2018). Amidst emerging global e-waste studies, few directly explore these already complex waste trades and materialities in relation to the general political ecology of water, flood control, dredging, and neoliberal ${ }^{4}$ ecological restoration. Even fewer focus on how this political-ecological challenge is unfolding in a West African context

\footnotetext{
${ }^{2}$ See Alexander and Reno (2012), Foote and Mazzolini (2012), Gabrys, Hawkins and Michael (2013), Liboiron (2015) and Hird (2012).

${ }^{3}$ See Grossman (2006), Gabrys (2011), Lepawsky (2014), Lepawsky and McNabb (2010), Kirby and Lora-Wainwright (2015a, b), Little and Lucier (2017), Lepawsky and Mather (2011), Lepawsky et al. (2014) and Lepawsky (2018).

${ }^{4}$ Our approach to neoliberalism is informed by Harvey (2007: 22), who argues that neoliberalism is "a theory of political economic practices which proposes that human well-being can best be advanced by the maximization of entrepreneurial freedoms within an institutional framework characterized by private property rights, individual liberty, free markets and free trade."
} 
where ocean-based e-waste trades have played a dominant role in shaping global narratives of e-waste pollution and digital age eco-destruction. Yet, where water is a more central focus, we confront a relational political ecology of watery things and politics of toxic blue economies (Winder and Le Heron 2017).

This article engages this particular domain of blue economic critique by focusing on Ghana in general and what we shall call "blue political ecologies of e-waste" in particular. Overseas shipments are a primary pathway of global e-waste trade and flows, yet the oceans, seas, lagoons, and waterways supporting port-to-port transportations is not a common theoretical thread in e-waste studies. Importantly, so-called e-waste 'hotspots' tend to be located close to waterways and water bodies (e.g., Guiyu in China and Agbogbloshie in Ghana). This article tunes into this area of blue political ecology by focusing on Ghana in general and what we call "blue political ecologies of e-waste" in particular. In the spirit of Sheila Jasanoff, we recognize that any proposed theoretical term-from the blue economy to blue political ecology — "is worth little unless it fits into the circumstances of the world, casting light on corners that need illumination" (Jasanoff 2015:24). For this reason, we find it important to highlight from the outset the dominant narratives and images of e-waste in Ghana that we seek to go beyond and rethink by accounting for the complex toxic watery landscape within which the e-waste economy in Accra, Ghana is situated.

The article is organized as follows. First, we provide a brief overview of the global political economy of ewaste, with particular emphasis on how e-waste trade and recycling economies emerged and took root in Ghana in particular. Next, we outline key concepts in political ecology and discard studies that help us make sense of the unfolding struggles around the Korle Lagoon. Grounded in ethnographic research, we then provide a social and environmental history of the Korle Lagoon, highlighting three key themes:

(1) a background on the development of the Agbogbloshie scrapyard that is a major e-waste economic hub on the urban landscape;

(2) the critical role of Korle Lagoon memory-making, or how Ghanaians talk about and remember the Korle Lagoon prior to the development of the Agbogbloshie scrapyard; and

(3) the ecological restoration efforts around the Korle Lagoon.

With these three themes, we also explore the connection between e-waste management and ecological restoration projects targeting the lagoon. Here, we draw on discussions of ethnographic research findings that highlight the place of lagoon restoration and wastewater discourse within a "green" e-waste intervention narrative. Finally, we discuss how thinking of the blue political ecology of e-waste can help us re-imagine and re-think e-waste trades, flows, and politics. We shall argue that in this stage of Ghana's neoliberalization, we need such a theoretical perspective to understand how e-waste trades, flows, and politics illuminate the critical place of water and hydropolitics in Ghana's ongoing struggle to negotiate the intersecting problems of urban regeneration, e-waste management, scrap-metal extraction, and lagoon ecological restoration.

\section{Exploring the socio-economic landscape of e-waste in Ghana}

The general narrative of e-waste in Ghana has, for nearly two decades, been largely anchored to a narrative of pollution, North-South waste trade imbalances, slum environmental destruction, child labor, and toxic exposures. Scenes of Agbogbloshie, the urban scrapyard that put Ghana on the global e-waste map, have circulated widely on social media and international media circles (CBC 2018; Guardian 2014; Ottaviani 2015; PBS 2009; Washington Post 2015). Many depictions of Agbogbloshie highlight the ways in which the burning of e-waste by informal laborers to extract valuable metals (i.e., copper and aluminum) poses a serious human and environmental health risk, particularly the contamination of the surrounding lagoon, known as the Korle Lagoon (Agyei-Mensah and OtengAbabio 2012; Akormedi et al. 2013; Caravanos et al. 2011; Chama et al. 2014; Huang et al. 2014; Wittsiepe et al. 2015).

Located in western Accra, the Korle Lagoon is an urban place and space of intensive land use, toxic waste disposal, social life, and various lagoon ecological restoration projects. The banks of the lagoon are settled by 
immigrants from Northern Ghana who fled declining economic opportunities ${ }^{5}$ and ethnic conflict in the early 1980s. The banks of the lagoon also serve as a solid waste landfill site for the burgeoning residential and economic activities in the vicinity, including the Agbogbloshie scrap market where e-waste is processed and traded. At the same time, it is also a zone targeted by international NGOs as a lagoon inundated with toxic pollutants, including e-waste runoff from the open burning of e-waste found at the Agbogbloshie scrap metal market (Little 2019). Given this broader socio-ecological friction, e-waste politics emerging in Agbogbloshie illustrate a case of postcolonial environmental injustice where plural injustices and violence underwrites conditions that makes e-waste processing possible at the site (Akese and Little 2018; see also Little 2019).

The Korle Lagoon is the site of lagoon ecological restoration projects. Both e-waste and lagoon restoration discourses and practices share a focus on decontamination and, ultimately, risk mitigation and toxic control. Our political ecology approach focuses on the hydro-politics emerging in an intervention environment fixated on lagoon restoration amidst neoliberal eco-modernization. We also situate these lagoon management politics within the peculiar history of Agbogbloshie, which is a contested landscape demonstrating broader urban political ecological struggles linked to the rapid urbanization of Accra. We find that within this broader political ecological struggle, lagoon restoration stands in direct conflict with the economies of waste that have developed along the lagoon. Thus, the blue political ecology approach to e-waste that we advance here draws attention to both the functionality and contestations of the lagoon as a sink and residue: to a perspective that sees spaces like the Korle Lagoon as tainted blue sinks, but also as assemblage and residue spaces of decontamination machines, technoscience, eco-project optimism, restoration skepticism, socio-political contention, and green neoliberalization.

Drawing on extended ethnographic research ${ }^{6}$ conducted between 2011 and 2018, we aim to contribute to the development of political ecological discussions of the "blue economy" in Africa by linking these debates to other urban political ecologies and geographies of electronic waste (Akese and Little 2008; Grant and Oteng-Ababio 2012; Lepawsky et al. 2015; Lepawsky 2018; Little and Lucier 2017; Pickren 2014). As Oteng-Ababio and Grant (2018) recently argued, strategies and discourses of urban regeneration in and around Agbogbloshie are composed of overlapping interests in urban decongestion and expansion of green space in and around the Korle Lagoon. As we shall argue, then, developing a political ecology perspective in this complex urban-marine context will call for drawing on new approaches that deal with overlapping front-and-center interests and porous socio-ecological struggle. For the 'blue political ecology of e-waste' that we speak to and wish to develop, we find fruitful influence from residue and sink thinking that acknowledges theoretical and material overflow, spillage, and leakage.

\section{Ghana within the global political economy of E-waste}

The political ecology of e-waste "is deeply entangled, although not always explicitly, with views and assumptions about existing biological-economic relations and is often enlivened by perceived opportunities to redress and develop afresh the content of these relations" (Winder and Le Heron 2017: 3). The relations of the blue economy are relations of water and waste in general, and lagoon water contamination and toxic e-waste spillage in particular. Ironically, water has long played a central role in the history of socio-environmental critiques of the electronics industry. In 1997, the Electronics Industry Good Neighbor Campaign made up of the Southwest Network

\footnotetext{
${ }^{5}$ Partly driven by the roll out of IMF and World Bank Structural Adjustment Programs (SAP) in the 1980s, which fundamentally altered Ghana's space economy (see Konadu-Agyeman 2000; Yeboah 2000). In the rural north in particular, which depended heavily on agriculture, the removal of agricultural subsidies pushed the populations to migrate to urban areas, especially Accra in search for waged labor. SAP also resulted in the privatizing of utilities and public housing in urban areas (Yeboah 2000), resulting in expansive housing which was beyond the means of new migrants and thus the proliferation of informal settlements and migrant enclaves like Agbogbloshie within the rapidly urbanizing city (Grant 2006; Farouke and Owusu 2012).

${ }^{6}$ We have each conducted mixed-method ethnographic research in Agbogbloshie, combining in-depth interviews, survey, and photo-ethnographic, document analysis methods. Both of us have made four fieldwork trips, Little since 2015, and Akese since 2010. Even though we carried out our ethnographic fieldwork separately, in the spirit of collaboration and synthesis, we chose a collaborative ethnographic approach and interpretation strategy, since our individual research findings tended to overlap. Additionally, we believe a more balanced and collaborative approach to research on Agbogbloshie is needed, especially amidst efforts to situate Agbogbloshie in critical theoretical debates. It was within such an attuned collaborative research environment that we began to reflect critically and more broadly about the relations of e-waste politics to Lagoon politics within a dynamic urban-marine space economy.
} 
for Environment and Economic Justice and the Campaign for Responsible Technology, published Sacred waters: life-blood of mother Earth. This book exposed the water scarcity and sustainability concerns of communities in the southwestern U.S., a region dominated by arid landscapes, in a time when water-dependent chip manufacturing facilities (or "fab labs") were on the rise. What this and other studies of the electronics-environment relationship have revealed, is that the production of electrical and electronic components, from silicon wafers to semiconductors, involves natural resource conflicts, with water contamination playing a primary role in these blue e-waste conflicts (Gabrys 2011; Little 2014; Smith, Sonnenfeld and Pellow 2006). We describe one such conflict by elucidating how e-waste conflicts spill over into discussions of lagoon contamination and restoration. We are equally interested in how spillage thinking helps reconfigure e-wastes' relation to water, especially water as a life-supporting thing, relation, metaphor, and worlding element (Anderson and Peters 2014; Steinberg 2013, 2015).

Flows of e-waste moving in and out of Ghana and fueling its scrap metal reuse economy are conditioned by a complex and uncertain global pattern of e-waste trades and "stewardship" initiatives and policies (see Grant and Oteng-Ababio 2012). As many have noted, e-waste circulates globally with limited stewardship, leaving certain regions of the Global South more vulnerable to highly toxic e-waste recycling and reuse economies (Blade et al. 2015; Lundgren 2012; Nnorom and Osibanjo 2008). Unlike flows of e-waste found in the Global North, waste arriving in Accra (and in the majority of the Global South) are generally sourced internationally (Grant 2006, 2016; Grant and Oteng-Ababio 2012), a reality that helps explain why and how the information technology (IT) revolution is changing established global e-waste trade dynamics. For example, instead of only the U.S., Canada, and countries in Europe, now China, India, and South Africa are emerging as dominant producers, sources, and destinations for electronic discard (Breivik et al. 2014; Furniss 2015; Lepawsky 2014; 2015).

The BAN Amendment to the original Basel Convention of 1992, outlines international regulations for the trade of hazardous wastes in order to minimize exploitation effects from the waste trade that are felt by non-Annex $\mathrm{VII}^{7}$ nations like Ghana. The Convention's treaty explicitly contains policies on the restriction of transboundary movements of hazardous wastes except where it is perceived to be in accordance with the principles of "sufficient management" or where "electronic stewardship" (e-Stewards) principles are imposed. In short, this legislation leaves large gaps in understanding, fosters misinterpretation, and reinforces contentious loopholes (Ahmad Khan 2016; Andrews 2009; Lepawsky 2014) as evidenced by the significant streams of toxic electronic discard in Ghana that in fact still originate from even signatory nations, mainly countries in the European Union but also from local consumption of new and second hand electronics in Ghana itself (Schluep et al. 2010) as well as from other African countries (Lepawsky 2018). As Richard Grant, an e-waste geographer and internationally recognized expert on ewaste issues in Ghana, recently pointed out,

Europe is by far the most important exporter of used computers to Ghana, followed by the United States. Much of this trade is considered donations to accord with the Basel Convention (which regulates the transport of hazardous waste), but non-working devices are often included in exports. (Grant 2016: 25)

Grant adds that "Flows into Ghana from Asia, the Middle East, and elsewhere in Africa are also rapidly increasing. Some of this regional traffic are European and North American traffic that is concealed by routing container traffic to Ghana via Hong Kong, Durban, Mombasa, and Dubai" (2016: 25). It is also suspected that negative media exposure in China has led to significant increases in Ghana's e-waste imports (Grant and OtengAbabio 2012).

Beyond the more global governance of e-waste instituted with the BAN Amendment, much more locally grounded initiatives have emerged mainly premised on the role of corporate social responsibility (CSR) and NGOs that claim to harness technical expertise to manage hazardous wastes in "green" and environmentally sound ways. The assemblage of environmental interventions deployed in Agbogbloshie, for instance, recycle common NGO

\footnotetext{
${ }^{7}$ The BAN Amendment (Basel Convention 2018) prohibits e-waste trade from what it calls 'Annex VII' countries (Organization for Economic Cooperation and Development (OECD), the European Community (EC) and Lichtenstein) to 'Non-Annex VII' countries. Although the Amendement was adopted in 1995, it is yet to be ratified by enough signitories for it to come into force (see Lepawsky (2015) for detailed discussion).
} 
interests and goals of turning places and spaces of extreme environmental suffering into sites of eco-neoliberal experimentation. In this way, the interventions in Agbogbloshie shadows other international e-waste advocacy approaches which tend to converge with the competitive economic discourse of the neoliberal state. Take the example of the NGO, Pure Earth.org (formerly known as Blacksmiths Institute) that has established a 'recycling facility' with automated wire stripping machines at Agbogbloshie. ${ }^{8}$ Fixed on global pollution control, Pure Earth.org (formerly known as Blacksmiths Institute) reinforces the neoliberal narrative of global e-waste toxicities. Pure Earth.org operates as a "solutions-based" organization yet is also supported by a network of "certification actors [that] play critical roles in securing narratives like 'digital development' or 'toxic trade' as the hegemonic commonsense understanding of the e-waste problem" (Pickren 2014:28). While on the surface it appears that ewaste NGO intervention in Ghana takes a serious approach to finding technical "solutions" to effectively reduce the environmental health risks of e-waste recycling labor, much of these interventions only help, if anyone, a tiny minority within Ghana's e-waste economy (Akese and Little 2018; Little 2019).

Ghana has been described as a key "neoliberal pacesetter" (Chalfin 2010: 29) in Africa, especially since its adoption of aggressive neoliberal reforms in the 1980s, largely attributed to a decline in global cocoa prices, as well as drought-related impacts. More recent debates over Ghana's e-waste problem are showing signs of yet another iteration of neoliberal interventions in global e-waste recycling economies, policies, and laws. The neoliberal moment is marked by "slum dialogue and improving infrastructure, particularly associated with bottomup ideas like rights to the city as well as economic growth, public-private partnerships (PPPs), and engagement of the private sector to build low-income housing" (Oteng-Ababio and Grant 2018: 4). According to a recent World Bank report, Ghana currently has 16 PPPs that are in implementation or active. Combined, these PPPs are valued at US\$6.85 billion, and the "long term outcome" of these investments is the creation of a "sustainable PPP market" in Ghana (World Bank 2018).

Furthermore, increased attention to private sector involvement in public waste management infrastructure in Ghana involves another layer of complexity that makes contemporary neoliberal critiques of Ghana's e-waste debate even more interesting. As noted earlier, more and more flows of e-waste are being generated within Ghana itself, instead of being simply the result of unequal and unjust North-South waste trades. Given this situation, as Grant (2016) points out, we need to be careful about how we couch the e-waste problem in Ghana within the broader global political economy of the e-waste trade and scrap metal trade. This cautionary stance is informed by the fact that Ghana has seen serious growth in its' own domestic flows of refurbished electronics: "Ghana imports used electronic devices from 147 countries. Electrical and electronic equipment importing commenced in 2004, and by 2009 the level of imports had risen to 215,000 metric tons, 70\% of which is e-waste. Another 984,000 tons of working electronic devices are in circulation, much of which is comprised of refurbished devices with a shorter life span (Schluep et al. 2012). This domestic stream is quickening: Ghana's participation in the IT revolution is considerable; mobile phone subscriptions in 2012 (per 100 people) surpassed the number in the United States. Scavengers operating at very high collection rates for electronic devices enable the urban mine to function" (Grant 2016:23).

As a key center dealing with these streams of waste, the so-called 'urban mining' that occurs at the Agbogbloshie scrap market, results in the production of highly toxic environmental transformations, a dilemma that has spawned other decontamination and restoration projects. Within Ghana's e-waste pollution debate, air pollution has been the strongest focus of interventions - as evidenced in Pure Earth's initiative-but, as we argue here, lagoon contamination and restoration attempts are also integral dimensions of Ghana's ongoing e-waste disaster story that for us exposes a dynamic blue political ecology plot worthy of unpacking.

\section{Producing sink and residue ecologies in the Korle Lagoon}

In their reflection on ecological restoration efforts at California's Salton Sea, Cantor and Knuth (2018:2) contend that "Political ecologists must more comprehensively and empirically explore what kinds of spaces are now being turned over to ecomodernist projects and postnatural design—and how, why, and with what impacts for

8 This initiative was primarily targeted at the practice of burning cables to retrieve copper. Burning is one of the major sources of air and soil pollution at the site. The facility therefore aimed to eliminate burning and thus reduce the risk of such pollution. See Little (2019) for a deeper analysis of the micropolitics of these "burner" interventions. 
whom." Landscapes primed for restoration such as the Korle Lagoon are often defined by waste, wastelands, or waste formations (Cantor and Knuth 2018; Dillion 2013; Gidwani and Reddy 2011; Goldstein 2013). Yet, recent discussions within critical studies of discards suggest that such framings, often lend to proposed solutions in term of disposal treatments and technologies, an act that naturalizes waste and wastelands (Gregson and Crang 2010; Gille 2007). Here we think comprehensively about the Korle Lagoon by drawing on the productive work of sink and residue metaphors, especially as these concepts are being re-imagined and theorized in discard studies (Gabrys 2009) and science and technology studies (Boudia et al. 2018). We also bring these concepts into conversation with blue political economy theory. Much like the imaginative intention of the "blue political economy" concept itself, it is critical to consider the ways in which "sinks are not only stores for unforeseen future environmental effects; they are also potent and laden imaginative spaces, signaling the dark, distant, and volatile reaches of environmental menace" (Gabrys 2009: 677). Most of the sinks and spaces of residue accumulation we think of are hydro-zones, or areas that are "blue" in nature. Places of industrial residue are commonly spaces for holding waste in general and wastewater in particular. The Korle Lagoon can be understood as a sink of sorts, but it also contains complex residues that beg the question: how does "residue" help us understand blue toxic environments? Following Boudia et al. (2018: 167), residues are important to consider because they "are at once by-products of extractive and industrial technology, history, and organization and also catalysts escaped from the lab or the landfill or the mine and urging into existence new biological, chemical, geological and sociotechnical worlds."

Located to the south-west of the central business district of Accra, the Korle Lagoon is the major runoff water receptacle for the city of Accra. All the major drainage channels in the city are connected to the Lagoon which ultimately drains into the Atlantic Ocean at the Gulf of Guinea. Together with parts of its largest tributary the Odaw River, the Lagoon covers a total surface area of $0.6 \mathrm{~km}^{2}$ and receives water from about a $400 \mathrm{~km}^{2}$ catchment area (Boadi and Kuitunen 2002; Karkari et al. 2006). With increasing urbanization and population explosion in Accra, about $60 \%$ of the Accra metropolis is within the catchment area of the Korle-Odaw Basin (Karkari et al., 2006), making the Lagoon significant in the natural hydrology system of this city of over 4 million people. Due to its location, the challenges of urban flood management in Accra is intricately linked to the functioning of the Korle Lagoon (Amoako 2016; Amoako and Boamah 2015; Amoako and Inkoom 2018).

In the decades following independence and particularly over the last twenty years, the Korle-Odaw basin has become a heavily polluted landscape which is thought of as an environmental disaster in need of mitigation, rather than in terms of its functions, diversity and carrying capacity. Historical evidence suggests that up until the 1960s, the lagoon supported commercial fisheries with other attendant socio-economic activities for the indigenous communities in its vicinity (Boadi and Kuitunen 2002; Biney and Amuzu 1995). A thriving fin and shellfish trade occurred along the Lagoon and served as a significant source of income for the nearby Ga villages and subsequent 'native towns' established under the colonial administration. The lagoon is also remembered as a hub of canoe transport for traders and a sacred site for Ga rituals (Roberts 2010). Importantly, it was also a reserve for aquatic biota, including habitat for major populations of wading birds (Ntiamoa-Baidu 1991). A long and complex history of intensive land use and associated pollution accounts for the current toxic sink and residue state of the Korle Lagoon. ${ }^{9}$ As the major receptacle of runoff in the city, some of the earliest gutters and sewer pipes first laid to drain the city all connect to the lagoon for final discharge into the sea (see Figure 1). In the absence of regular upgrades, however, and with increasing volumes of discharge coupled with the open nature of the drains, leaks and overflows from sewers are a primary cause of the Lagoon's contamination (Onohua 2016; Figure 2). Until very recently when the 'Lavender Hill' ${ }^{10}$ fecal waste treatment plant become operational, untreated fecal waste directly emptied into the ocean by the city authority, Accra Metropolitan Assembly (AMA), backwashed into the Lagoon compounding its contamination. Additionally, the banks of the basin are lined with industrial activities including a paint factory, breweries, textile factories, garages and vehicle repair workshops, which all discharge their effluent into the lagoon (Karkari et al. 2006). Effluent (including mortuary waste) from the nearby Korle Bu Teaching Hospital is also discharged into the lagoon. Uncontrolled discharges, open defecation and dumping of waste directly into the lagoon also occur from the ever-growing high-density low-income settlements within its vicinity.

\footnotetext{
${ }^{9}$ As part of our ethnographic methods, we also analyzed secondary documents to learn about the social and environmental history of the Korle Lagoon.

10 The area is sarcastically known as 'Lavender Hill' because of the emanating stench from the fecal discharge into the sea.
} 
In the absence of garbage collection services, an additional source of toxic residue in the lagoon is household and industrial waste from the Old Fadama informal settlement and the adjacent Agbogbloshie scrap yard. To more fully understand this residue source, one needs to consider the history and practice of land reclamation along the lagoon. A large portion of the Agbogbloshie scrap yard and the Old Fadama settlement sits on land that is largely part of the lagoon. Over time, and as the scrap yard and settlement continued to grow, residents resorted to filling in the lagoon with sawdust to reclaim land and build further on its edges (Farouk and Owusu 2012). This reclaimed land caves in frequently, releasing sawdust into the water. Contrary to a popular narrative attributing the so-called "death" of the lagoon to the marginalized Old Fadama informal settlement and the economies they have established along the lagoon (prominently featuring e-waste processing), toxic residues and runoff from the Old Fadama slum and Agbogbloshie scrap yard at the upper reaches of the Lagoon are only a recent addition to the long and growing list of pollution sources. ${ }^{11}$ The sources of the lagoon's pollution are varied, and importantly predate the adjacent ewaste industry along its banks, which only came into prominence in the late 2000s.

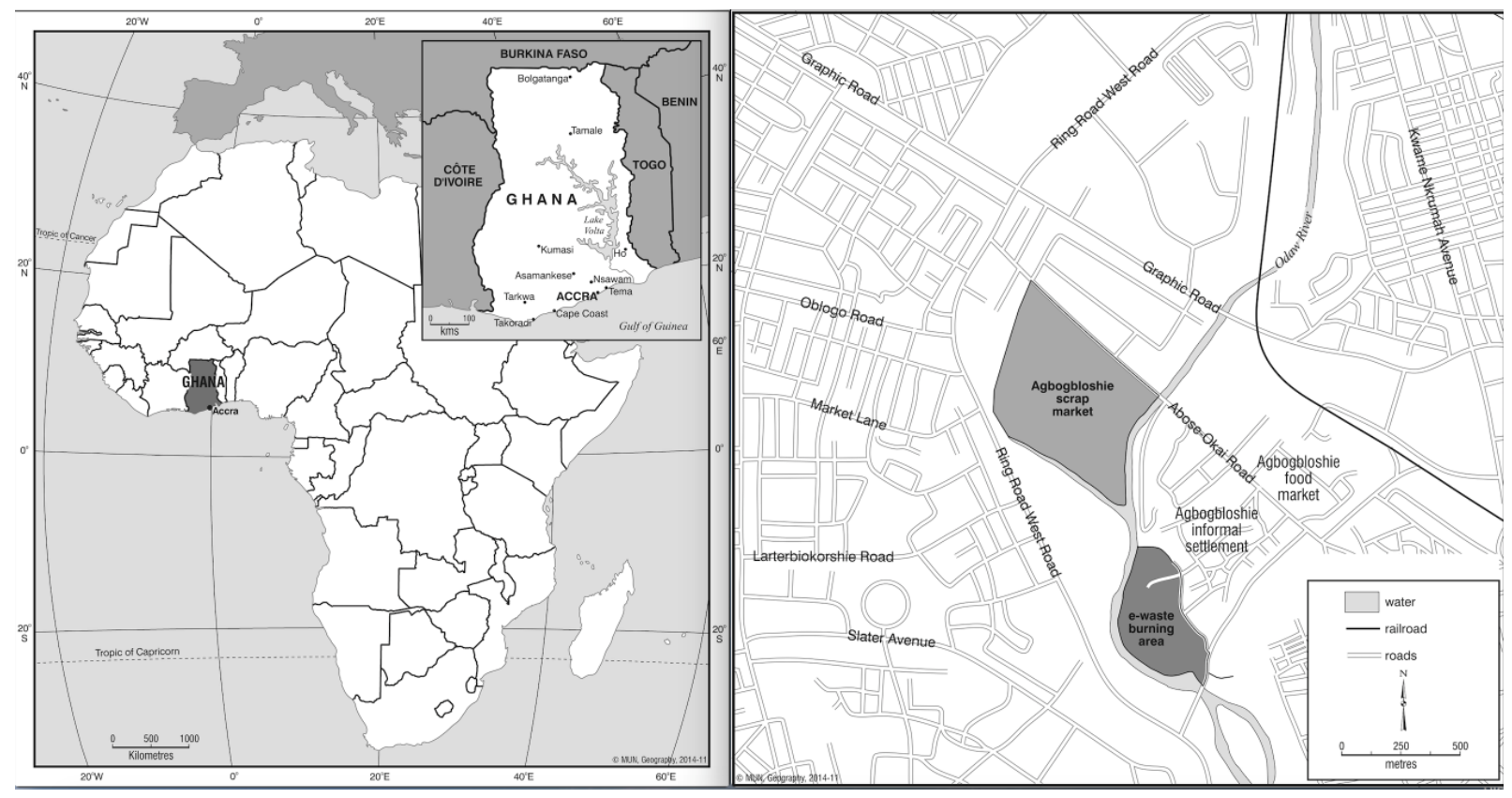

Figure 1: Site Map of Agbogbloshie and the general Korle Lagoon area. The Lagoon continues to the south. Source: Akese and Little 2018.

Still, regardless of the pollution source studies available, the Korle Lagoon has been anchored to a "pollution nightmare" narrative. Here is one example from a journalist writing about the lagoon just around the same time the Agbogbloshie e-waste conflict first caught the attention of the international environmental NGO, Greenpeace International:

Theo Anderson, a Ghanaian ecologist, moved gingerly up to the edge of the pond, and remarked in a friendly way: 'If you fall in there, you'll be dead in minutes'. He wasn't joking. The Korle Lagoon in Ghana's capital of Accra is one of the most polluted places on earth. It is a natural depression that

\footnotetext{
${ }^{11}$ This is not in any way to understate the damaging effects of e-waste processing on the Lagoon. Obviously, there are numerous and highly toxic chemicals and materials (lead, cadmium, PCBs, PBDEs) contained in e-waste which compounds the problem. Instead, we emphasize this point to draw attention to the ongoing zone of social and ecological contamination at play when looking at the broader economies facilitated by the Lagoon
} 
serves as a cesspool for most of the city's industrial and human waste-it is an environmental nightmare. Owing to the pollution, no living thing, animal or plant, has been able to grow in it for years. Even boaters steer clear of its thick, black nauseating syrup. Its stench wafts back to envelop the adjoining shantytown that is home to hundreds of families who, because they have no sanitation facilities, have turned the shores of the lagoon into a giant latrine (Bourgoing 2002).

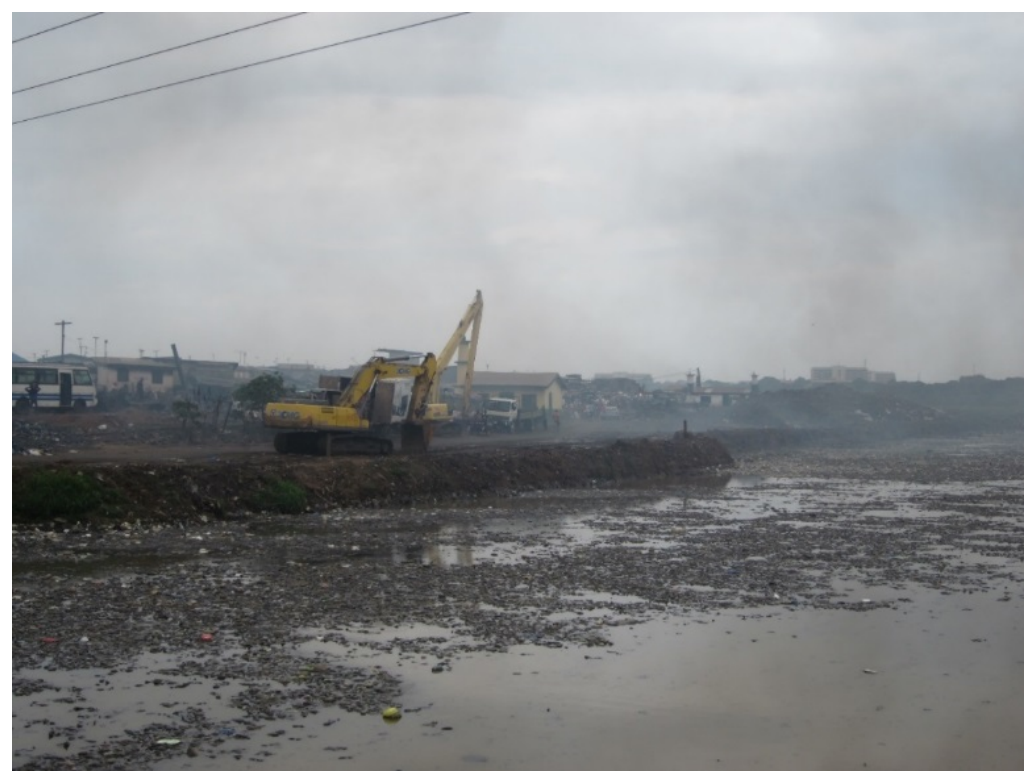

Figure 2: The Korle Lagoon's "black nauseating syrup." Photo by Peter C. Little

The Lagoon is not only a multi-use marine environment and sink for toxic water, vegetation, and an extraction zone for scrap metal economies, but also a place and space of social and environmental memory, a site of green memory-making. In a rare historical account on the Korle Lagoon, Roberts (2010: 346) writes that "The Korle Lagoon is also a palimpsest of memories for the people of Accra, a place where, to use Pierre Nora's phrase, "memory crystallizes and secretes itself." 12 As already noted the lagoon occupies a central place in the history of Accra as a Ga settlement and continue to be a sacred site revered as a deity by the indigenous Ga communities living around the area (Dakubu 1997; Grant 2009; Quayson 2014). During the colonial era, the British colonial administration's visions of turning the lagoon into a deep-water harbor and reengineering the lagoon as a malaria control measure clashed with the spiritual practices and beliefs of the local Ga populations for whom the lagoon was a sacred place (Roberts 2010). In the period (the 1960s) after Ghana's independence from British colonial rule, the government declared the area surrounding the lagoon as a green wedge to be appropriated into communal town parks mainly for leisure and recreation (Government of Ghana, Ministry of Housing 1958: 28). This vision of what the Korle was and could have been featured prominently in the memories of those who recount the "pollution nightmare" narrative.

In fact, when the first Ghanaian environmental journalist, Mike Anane, exposed the Agbogbloshie e-waste problem, he was very open about the linkage between his environmental advocacy and his own eco-biography and memory. As he recently put it, "What was once a green and fruitful landscape is now a graveyard of plastics and skeletons of abandoned appliances" (Ottaviani 2015). In one ethnographic interview ${ }^{13}$ with a middle-aged resident

\footnotetext{
12 The phrase is from: Pierre Nora (1989), Between memory and history: Les lieux de mémoire. Representations 26: 7-24.

${ }^{13}$ As with most ethnographic interviews conducted, this informant spoke in Pidgin English, a linguistic form marked by the use of English in concert with the local vernacular. In this linguistic case, English is the base language used, but words are dropped or tweaked in ways that disregard standardized English grammar rules. In an effort to accurately document responses and reveal interview data, we find it culturally appropriate to use the spoken vernacular of our informants.
} 
of Sabon Zongo, a Hausa speaking community adjacent to Agbogbloshie with a deep social presence in this area of Accra (Pellow 2008), the lagoon is remembered as a childhood play area and place of adventure:

It was so green and we used to chase and trap rats. We were kids. It was a big place with so many trees. Nothing like it is now. So much has changed. I think that is how it is bad. No more green. Now all there is is waste and smoke. So much has changed there. (Interview 7/22/2016)

The loss of a lush lagoon to toxic heavy metal runoff from e-waste processing and disposal of organic material is also an underlying stimulus for ecological restoration projects and focus of studies exploring marine toxicity in the lagoon (Hosoda 2014; Huang et al. 2014). The impact on marine life was a common theme of interviews conducted with residents in the surrounding area, many of whom recreate along the Korle Lagoon:

Many people run along this part of the Ring Road [a major road that arcs around Accra]. We run to the ocean that is the end of the lagoon. That is where the fisherman are and you see their boats in the black water. It is so so polluted. You know the smell. [Laugh]. When I was a boy, we would fish here. Now look at it. And you see the boats. They still fish in it. Everyone eats pollution here, even if the lagoon is dark. Even if it is there like that. (Interview 8/2/2017)

Despite the multiple sources of the lagoon's ongoing contamination, a primary targeted cause is the informal recycling of discarded electrical and electronic equipment (or e-waste) in Agbogbloshie. E-waste processing at Agbogbloshie is part of the flourishing informal sector in a rapidly urbanizing Accra (Grant and Oteng-Ababio 2012; Oteng-Ababio 2012). In fact, the history of Agbogbloshie scrap yard is intricately tied to broader processes transforming the city of Accra. Agbogbloshie began as a general scrap yard specializing in vehicle repair, automobile spare parts trading, welding, and tire servicing. In the early 1990s the city authorities in an attempt to decongest the central business district of Accra relocated hawkers and Accra's yam market to the edge of the Korle Lagoon. This relocation made it possible for the scrap market to build from the ground up, offering a space for various services such as vehicle repair, spare parts trading, welding, auto mechanics, and tire servicing that were crucial to the operation of the yam trucks (Grant 2006). The development of the scrap yard was further facilitated by the inflows of economic migrants primarily from Ghana's northern regions, which suffered diminished agricultural opportunities and compounding inter-tribal conflicts at the time (Little forthcoming). In the absence of job opportunities in the formal sector, precarious options in the informal sector, and rising housing costs and rent in Accra for the urban poor, most of these migrant laborers found residency in the Agbogbloshie/Old Fadama area. Importantly, in an environment of rapid growth in informal sector activities around the broader Agbogbloshie area, e-waste processing quickly become a part of the Agbogbloshie scrap market that started around vehicle repair (Davis, Akese and Garb 2018; Grant and Oteng-Ababio 2012; Oteng-Ababio 2012).

The Agbogbloshie scrap market plays a central in Accra's industrial economy. It is a booming informal economic hub and, much like other regions of greater Accra, has since the early 1980s become an "active frontier" of neoliberalism (Chalfin 2010) and more recently become a space of contentious "green" intervention (Little 2016, 2019, forthcoming). Following Ferguson (2005), we might consider how so-called "clean up" and toxic waste mitigation in the Korle Lagoon is a matter of neoliberal shifts in the very management of crisis across Africa:

According to the mythology of neoliberal globalization, the reforms of Africa's 'structural adjustment' were supposed to roll back oppressive and overbearing states and to liberate a newly vital 'civil society'. The outcome was to be a new sort of 'governance' that would be both more democratic and more efficient. Instead, the best scholarship on recent African politics suggests that the 'rolling back' of the state provoked or exacerbated a far-reaching political crisis. As more and more of the functions of the state were 'outsourced' to nongovernmental organizations (NGOs), state capacity deteriorated rapidly. (Ferguson 2005: 379) 
As a primary node of a vibrant scrap metal trade industry that generates between US\$200 and \$300 million in revenues annually in Ghana, the Korle Lagoon area is a busy political-economic space that inflects global trends, primarily "specific macroeconomic and macropolitical interventions geared to the promotion of private enterprise and the market logic strongly associated with economic globalization and the spread of multinational capital" (Chalfin 2010: 4). It reflects global environmental trends, crises, and politics, especially when it comes to e-waste, flood vulnerability, lagoon contamination, and greenhouse gas emissions. Straddling what Oteng-Ababio and Grant (2010: 8) call a "sustainability dilemma", some activities at Agbogbloshie such as e-waste recycling and reuse simultaneously contribute to and work against a greener circular economy. As Ghana faces climate change challenges, much like all its neighboring countries in equatorial Africa, Agbogbloshie has quickly become a target of 'climate change blame.' For example, sitting right at the banks of the Lagoon, the settlements flood during the peak raining seasons of June-July. Furthermore, with blame for the supposed death of the Lagoon hanging over the settlements' shoulder, residents of Agbogbloshie/Old Fadama live in constant threat of eviction from the city authorities whose default policy for dealing with urban floods is evictions of communities living close to waterways. For example, in the wake of a twin flood and fire disaster that claimed the lives of over 150 people in Accra on June $3^{\text {rd }}$ 2015, parts of Agbogbloshie/Old Fadama were violently demolished (Lepawsky and Akese 2015). In the process, over 20,000 residents, mostly women and children were rendered homeless and struggled to find shelter from harsh summer rainfall.

Beyond the environmental health challenges of e-waste processing (e.g., open burning of toxic copper cables and wires) that first attracted international NGOs to Agbogbloshie, Ghana's climate change challenges also helped turn a critical eye on the pollution emitting from Agbogbloshie, a situation blamed for causing severe urban air pollution and increasing Ghana's overall carbon footprint. Ghana has responded to this challenge through active participation in international climate change negotiations and domestic planning through sustainable growth where possible, and through various domestic initiatives (GASDA 2014). However, Ghana faces serious impediments to "sustainable" growth and the ability to adapt to climatic changes already ongoing. Perhaps the most limiting factor is finance, as Ghana projects it will need roughly US\$22.6 billion to carry out "the pledge," a nationally determined contribution it made as part of its obligations under the Paris Agreement. Of that money, Ghana projects that US $\$ 16.3$ billion will be required from international donors, which gives some indication of the financial barriers the country faces in achieving targeted "sustainability" goals. To us, the political ecology of e-waste in Ghana connects to these broader economic and environmental trends, crises, and sustainability politics. Attending to these connections is one way to contest and overcome the all-too-common pattern of reducing Agbogbloshie to a place and space of e-waste dumping or treating Agbogbloshie as the epicenter of toxic struggle in Ghana, a counternarrative that has been the subject of recent scholarship (Akese and Little 2008; Little 2019).

\section{Remediating e-waste residue: the Korle Lagoon Ecological Restoration Project (KLERP)}

Currently, there are attempts to rehabilitate the lagoon through Korle Lagoon Ecological Restoration Project (KLERP), an urban sustainability project that pushed for and completed a feasibility study and a detailed design study for the restoration of Korle Lagoon and its river system in the metropolitan area of Accra. The KLERP is overseen by Ghana's Environmental Protection Agency (EPA), the Accra Metropolitan Assembly (AMA), and is a project that receives international oversight and financial support from the OPEC Fund for International Development, the Arab Bank for Economic Development in Africa, the Kuwait Fund for Arab Economic Development, the Belgium Government Supported Export Credit, and the Standard Chartered Bank of London. As of 2018, roughly US\$120 million has been spent on the KLERP. As the Environmental Justice Atlas research project has recently pointed out, the KLERP is tainted by urban slum redevelopment and displacement politics, which ultimately come down to historic land disputes (EJ Atlas 2017). As this project notes: "The conflict over the land area is rooted in clashes between elites and colonial administrators over land tenure policies of 1914-1920. Since 1991, there have been repeated eviction actions in Old Fadama, in attempts to remove the northern settlers, who are still called 'outsiders' despite their extended tenure in the locale" (EJ Atlas 2017).

Yet, amid this land conflict, KLERP has moved forward with efforts to re-dredge the lagoon and the inflowing river system to restore drainage, sewerage, sanitation and urban planning goals that fit within the sustainability scope of to the project. In this way, the lagoon restoration project showcases the complexities of urban lagoon restoration in Ghana and highlights a basic tenet of blue political ecology that we draw attention to, that such 
a political ecology is both about things "blue", like water quality in the lagoon, but also about many other matters of sustainability dealing with non-aquatic life. The ongoing lagoon restoration project, for example, is also about the reclamation of parts of the surrounding lowlands as parkland and developing recreational spaces, an elite aspiration to render Accra a millennium city devoid of the current Korle Lagoon eyesore (Afenah 2009). It was also a project that led to the installation of a massive urban wastewater treatment plant and the development of other infrastructure to prevent future contamination of the lagoon. All of these hydro-ecological projects are informed by a political economy bolstered by techno-scientific expertise and eco-machinery.

For example, dredging of the lagoon has recently been modernized with state-of-the-art dredging technologies, including the deployment of a new Watermaster dredging machine, developed by the Finnish company Aquamec (see Figure 3 and 4). The company's Watermaster model is claimed to bolster Aquamec's overall "water mastering" mission, which is to "constantly improve Watermaster's capabilities to work effectively in shallow water environmental dredging project", to "minimize the environmental load arising from the use of Watermaster", to "take ecological sustainability into account in our own activities", "to meet all statutory requirements and official regulations, wherever we operate", and finally, to remain "committed to continuous improvement of our Environmental Management" (Aquamec webpage 2018).

The future of KLERP and its capacity to fully 'restore' the Korle Lagoon remains unknown as residents demand action beyond the occasional dredging that the project has been reduced to (Ghana Web 2015). For us, the pollution of the lagoon from e-waste processing and subsequent remediation attempts targeting both airborne toxicities and the lagoon, illustrate not only the elusive boundary between ocean and land, but also a space of boundary crossing and spillover occurring between e-waste "management" and ecological "restoration" in a West African neoliberal environment with a "context-contingent and material-discursive character" (Heynen et al. 2007: 13).

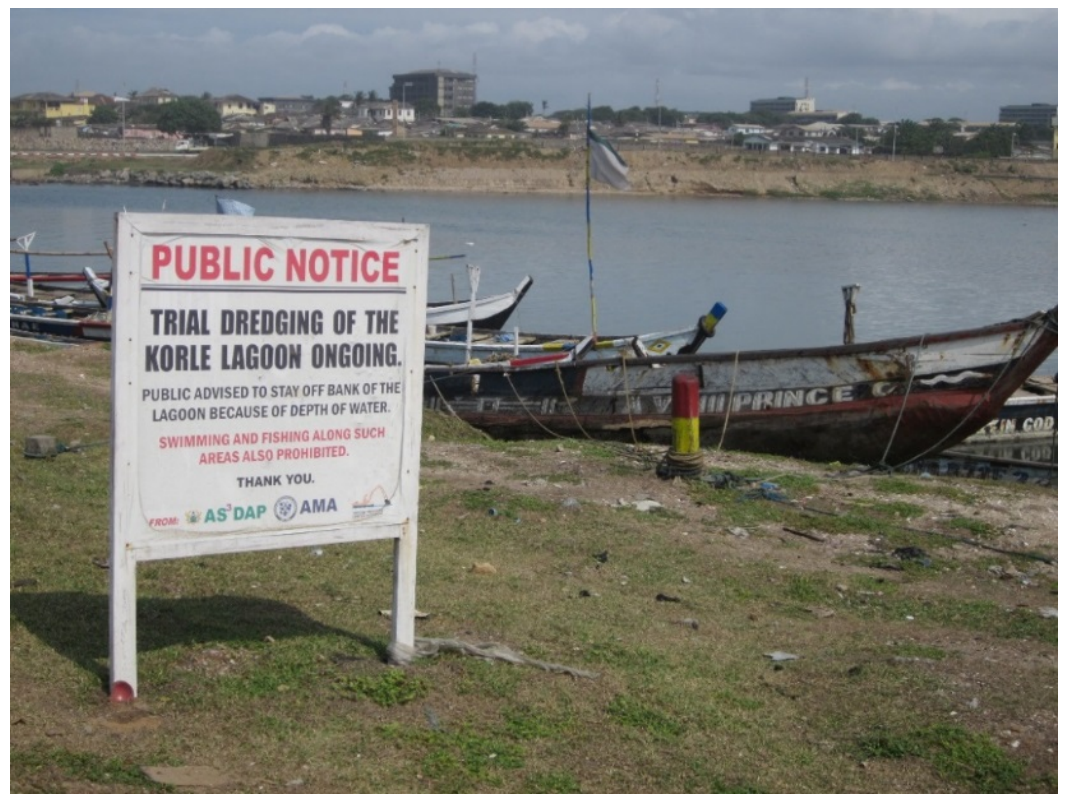

Figure 3: Ongoing dredging and water avoidance messaging. Photo by Peter C. Little.

\section{Engaging with a blue political ecology approach to e-waste}

In this article, we have explored one possible research angle of a blue political ecology approach to e-waste in Ghana. While a multi-sited ethnography of e-waste focused squarely on West African port economies and transoceanic shipping would be a fantastic route to take in advancing a blue political ecology theory of e-waste, we have instead drawn on our shared ethnographic experiences to make sense of Ghana's e-waste environmental politics 
through the lens of lagoon contamination and neoliberal management. This led us to intentionally consider our own practice of theoretical and material boundary crossing. As Gabrys (2009) has it, "crossing boundaries and enacting various processes of impurification (or para-sitism) can...become a strategy for questioning the politics and materiality of purification. Boundaries are sites for articulating ways of imagining waste, and for registering the ways in which it is embodied-socially, politically, geographically, materially, and ecologically" (Gabrys 2009: 676). Our primary goal aimed to reimagine e-waste in relation to lagoon contamination and restoration and to rethink boundaries in radical ways, but not necessarily in ways that detract from concreteness and the various materialities of toxic discard and the lagoons receiving their toxic metal leaching. Rethinking boundaries, in this sense, is both a productive element of our blue political ecology of e-waste and a critical approach to the blue e-waste economy. This approach to boundaries is a recognized focus of blue economy theory: "There is an underlying ocean-coastland territorial situatedness to every activity, and every perspective, and narrative on activities" (Winder and Le Heron 2017: 15). Therefore, narratives of and interventions in the Korle Lagoon shape and are informed by processes of rethinking the material boundaries of the "situation" itself, but also processes of situating this multi-use urban marine space within the terms of ongoing spillage, mitigation, and contentious neoliberalization.

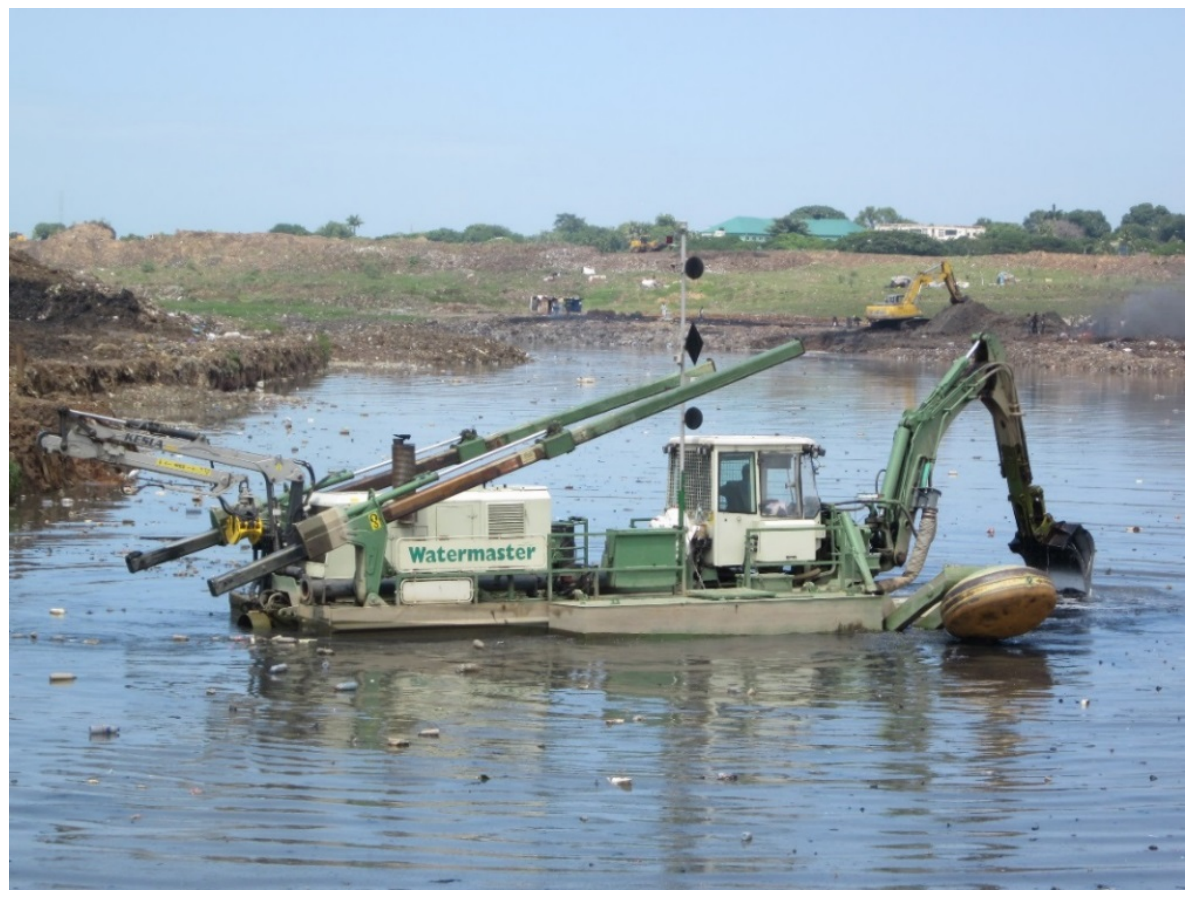

Figure 4: The Watermaster in Action. Photo by Peter C. Little.

As Gabrys (2009: 669) asserts in her 'theory of sinks', at the intersection of technology, nature and waste lie the perceived purity and impurity of environments. During ethnographic fieldwork in 2017, one of us (Little), spoke with a merchant selling shoes on a bridge that crosses the Odaw River, which feeds into the lagoon. A migrant from northern Ghana who moved to Agbogbloshie/Old Fadama in 2013, we talked while we watched the Watermaster in action (Figure 4). He was explicitly skeptical of the "mastery" that this machine claimed to achieve: "This is what they do here. No way it fix this. Look! So much plastic and waste in the water. What will it do? No. Nothing will fix the Korle." Yet, despite this local skepticism, the machines, the NGOs, and the PPPs continue, even if these interventions often dissolve before they even begin to actually mitigate toxic risk. One Ghana-based environmental NGO, the Friends of Rivers and Water Bodies, which was established in 1989 and receives funding from UNEP and the World Bank, has recently developed a project focusing on the Korle Lagoon. Beyond the development of a 
website, it is difficult to actually track the efficacy of such projects, even if in digital space they appear to be doing good "green" work that will benefit the socio-natural environment of the lagoon.

Moreover, expert technoscience partnerships provide another key dimension of lagoon decontamination narratives, interventions, and politics. Efforts to study and mitigate the toxic overload witnessed in the Korle Lagoon has been guided by researchers at the University of Ghana and international research collaborators. One recent report from such a collaboration (Squire 2018) is explicit about the so-called "migrant" problem being the most critical source of the lagoons' toxicity:

The Korle Lagoon used to be a freshwater ecosystem that once boasted an abundance of fish, crab and other forms of aquatic biota that contributed to food security and also provided a means of livelihood for residents around its vicinity. In the past few decades, however, the lagoon has become heavily polluted and an environmental disaster due to the combined effects of uncontrolled urbanization, politics and mismanagement. The banks of the Korle Lagoon have been transformed into human habitats by migrants, mainly from Ghana's northern region, whose activities largely contribute to problems emerging in the area. These migrants engage in commercial and other activities that contribute to the generation of massive amounts of waste including dangerous pollutants that end up in the lagoon. (Squire 2018: 117)

\section{Conclusion}

To conclude, we have turned to hydro-politics, blue political economy critique, and the metaphorical import of sinks and residues to go beyond the usual cul-de-sacs of toxicity and environmental plunder in one of Africa's most notorious urban e-waste landscapes. This venture-even a detour for our own studies of e-waste politics in Ghana-has raised several new questions for us: How do e-waste politics leak or spill into discussions of the blue economy in Ghana? What is the "blue" effect of toxic e-waste in an intervention environment dominated by uncertain "green" ecological restoration projects? What is the role of metaphor, and especially the concepts of sinks and residues, for rethinking the theoretical and material focus of the broader blue political ecology of e-waste in general and in Africa in particular?

As recent scholarship has pointed out (Oteng-Ababio and Grant 2018), Agbogbloshie reveals paradoxical management discourses, interests, and goals. The urban planning forces at play in this industrial zone of Accra are caught in a complex tangle, leading some to argue for "a deeper appreciation for the inherent tension between urban policy documents that convey the policy process as linear, systematic, and democratic and implementation that is far less democratic, messy, contested, and dynamic" (Oteng-Ababio and Grant 2018: 9). As the e-waste economy and environmental restoration interventions co-inhabit this urban landscape, so do the paradoxes of these entangled practices of ecological purification, urban renewal, and pollution control. As we have tried to illustrate here, lagoon restoration and e-waste management come together in the realms of lagoon clean-up, decongestion, and decontamination. We hope that more ethnographic political ecology, not less, is advanced in this now popularized West African e-waste context, if not simply to draw attention to and acknowledge the residues and lives caught in the middle of watery urban e-waste projects, discourses, politics, and transformations.

\section{References}

Afenah, A. 2012. Engineering a millennium city in Accra, Ghana: the Old Fadama intractable issue. Urban Forum 23: 527-540.

Agyei-Mensah, S. and M. Oteng-Ababio. 2012. Perceptions of health and environmental impacts of e-waste management in Ghana. International Journal of Environmental Health Research 22(6): 500-517.

Akese, G. and P.C. Little. 2018. Electronic waste and the environmental justice challenge in Agbogbloshie. Environmental Justice 11(2): 77-83.

Akormedi, M., E. Asampong and J.N. Fobil. 2013. Working conditions and environmental exposures among electronic waste workers in Ghana. International Journal of Occupational and Environmental Health 19(4): 278-286. 
Alexander, C. and J. Reno (eds.). 2012. Economies of recycling: the global transformation of materials, values and social relations. London: Zed.

Amoako, C. 2016. Brutal presence or convenient absence: the role of the state in the politics of flooding in informal Accra, Ghana. Geoforum 77: 5-16.

Amoako, C. and D. Inkoom. 2018. The production of flood vulnerability in Accra, Ghana: re-thinking flooding and informal urbanisation. Urban Studies 55: 2903-2922.

Amoako, C. and F. Boamah. 2015. The three-dimensional causes of flooding in Accra, Ghana. International Journal of Urban Sustainable Development 7: 109-129.

Anderson, J. and K. Peters (eds.). 2014. Water worlds: human geographies of the ocean. Aldershot: Ashgate.

Andrews, A. 2009. Beyond the ban: can the Basel Convention adequately safeguard the interest of the world's poor in the international trade of hazardous waste? Law, Environment and Development Journal 5(2): 167-184.

Aquamec webpage. 2018. https://watermaster.fi/

Arthur, P. 2006. The state, private sector development, and Ghana's 'golden age of business'. African Studies Review 49(1): 31-50.

Basel Convention. 2018. Amendment to the Basel Convention on the Control of Transboundary Movements of Hazardous Waste and their Disposal. Available at http://www.basel.int/Countries/StatusofRatifications/BanAmendment/tabid/1344/Default.aspx

Blade C.P., F. Wang, R. Kuehr and J. Huisman. 2014. Global E-Waste Monitor 2014: quantities, flows and resources. Bonn: United Nations University, IAS - SCYCLE. Accessed at https://i.unu.edu/media/ias.unu.edu-en/news/7916/Global-E-waste-Monitor-2014-small.pdf

Boadi, K., and M. Kuitunen. 2002. Urban waste pollution in the Korle Lagoon, Accra, Ghana. The Environmentalist 22: 301-309.

Boudia, S. A.N.H. Creager, S. Frickel, E. Henry, N. Jas, C. Reinhardt, and J.A. Roberts. 2018. Residues: rethinking chemical environments. Engaging Science, Technology, and Society 4: 165-178.

Bourgoing, R. 2002. Ghana: the nightmare lagoons. Accessed at http://www.bourgoing.com/ghana.htm

Breivik, K., J.M. Armitage, F. Wania and K. Jones. 2014. Tracking the global generation and exports of e-waste: do existing estimates add up? Environmental Science and Technology 48(15): 8735-8743.

Cantor, A. and S. Knuth. 2018. Speculations on the postnatural: restoration, accumulation, and sacrifice at the Salton Sea. Environment and Planning A: Economy and Space 1(2): 527-544.

Caravanos, J., E. Clark, R. Fuller and C. Lambertson. 2011. Assessing worker and environmental chemical exposure risks at an E-Waste recycling and disposal site in Accra, Ghana. Journal of Health and Pollution 1(1): 1625.

CBC. 2018. The world's largest e-waste dump is also home to a vibrant community | CBC Radio. Accessed at https://www.cbc.ca/radio/spark/412-1.4887497/the-world-s-largest-e-waste-dump-is-also-home-to-avibrant-community-1.4887509

Chama, M.A., E.F. Amankwa and M. Oteng-Ababio. 2014. Trace metal levels of the Odaw river sediments at the Agbogbloshie e-waste recycling site. Journal of Science and Technology (Ghana) 34(1): 1-8.

Chalfin, B. 2014. Public things, excremental politics, and the infrastructure of bare life in Ghana's city of Tema. American Ethnologist 41(1): 92-109.

COHRE. 2004. A precarious future: The informal settlement of Agbogbloshie Accra, Ghana. Accra: The Centre on Housing Rights and Evictions. Accessed at https://www.mypsup.org/library_files/downloads/Report\%20on\%20the\%20Informal\%20Settlement\%20of \%20Agbogbloshie,\%20Ghana.pdf

Dakubu, M. 1997. Korle meets the sea: a sociolinguistic history of Accra. Oxford: Oxford University Press.

Davis, J-M., G. Akese and Y. Garb. 2018. Beyond the pollution haven hypothesis: where and why do e-waste hubs emerge and what does this mean for policies and interventions? Geoforum 98: 36-45.

Dillon, L. 2013. Race, waste, and space: brownfield redevelopment and environmental justice at the Hunters Point Shipyard: waste, race and space. Antipode 46(5): 1205-1221. 
EJ Atlas. 2017. Environmental Justice Atlas. https://ejatlas.org/. Local page: https://ejatlas.org/conflict/accrasagbogbloshie-electronic-waste-dump

Farouk, B.R, and M. Owusu. 2012. 'If in doubt, count': the role of community-driven enumerations in blocking eviction in Old Fadama, Accra. Environment and Urbanization 24(1): 47-57.

Ferguson, J. 2005. Seeing like an oil company: space, security, and global capital in neoliberal Africa. American Anthropologist 107(3): 377-382.

Foote, S. and E. Mazzolini (eds.). 2012. Histories of the dustheap: waste, material cultures, social justice. Cambridge, MA: MIT Press.

Furniss, J. 2015. Alternative framings of transnational waste flows: Reflections based on the Egypt-China PET plastic trade. Area 47(1): 24-30.

Gabrys, J. 2009. Sink: the dirt of systems. Environment and Planning D: Society and Space 27(4): 666-681.

Gabrys, J. 2011. Digital rubbish: a natural history of electronics. Ann Arbor: University of Michigan Press.

Gabrys, J., G. Hawkins and M. Michael (eds.). 2013. Accumulation: the material politics of plastics. London: Routledge.

Ghana Shared Growth and Development Agenda (GSGDA). 2014. Ghana Shared Growth and Development Agenda (GSGDA) II, 2014-2017 - Vol I: Policy Framework. National Development Planning Commission.

Ghertner, D.A. 2011. Green evictions: environmental discourses of a 'slum-free' Delhi. In R. Peet, P. Robbins and M.J. Watts (eds.). Global political ecology. London: Routledge. Pp. 145-165.

Gille, Z. 2007. From the cult of waste to the trash heap of history: the politics of waste in socialist and postsocialist Hungary. Indiana University Press.

Goldstein, J. 2013. Terra economica: waste and the production of enclosed nature. Antipode 45: 357-375.

Government of Ghana, (Ministry of Housing). 1956. Accra: a plan for the town. Retrieved from http://mci.ei.columbia.edu/mci/files/2013/03/Accra-Town-Plan-1958.pdf

Grant, R. 2006. Out of place? Global citizens in local spaces: a study of the informal settlements in the Korle Lagoon Environs in Accra, Ghana. Urban Forum 17: 1-24.

Grant, R. 2016. The "Urban Mine" in Accra, Ghana. RCC Perspectives 1: 21-30.

Grant, R. and M. Oteng-Ababio. 2012. Mapping the invisible and real 'African' economy: urban E-waste circuitry. Urban Geography 33: 1-21.

Gregson, N. and M. Crang. 2010. Materiality and waste: inorganic vitality in a networked world. Environment and Planning A 42: 1026-1032.

Grossman, E. 2006. High tech trash: digital devices, hidden toxics, and human health. London: Island Press.

Guardian, The. 2014. Agbogbloshie: the world's largest e-waste dump - in pictures. The Guardian. Accessed at https://www.theguardian.com/environment/gallery/2014/feb/27/agbogbloshie-worlds-largest-e-wastedump-in-pictures

Heynen, N. J. McCarthy, S. Prudham and P. Robbins 2007. Introduction: false promises. In N. Heynen, J. McCarthy, S. Prudham and P. Robbins (eds.). Neoliberal environments: false promises and unnatural consequences. New York: Routledge. Pp.1-22.

Hird, Myra J. 2012. Knowing waste: Towards an inhuman epistemology. Social Epistemology 26(3-4): 453-469.

Hosoda J., J. Ofosu-Anim, E.B. Sabi, L. Gifty Akita, S. Onwona-Agyeman, R. Yamashita and H. Takada. Monitoring of organic micropollutants in Ghana by combination of pellet watch with sediment analysis: Ewaste as a source of PCBs. Marine Pollution Bulletin. 86: 575-581.

Huang, J., P.N. Nkrumah, D.O. Anim and E. Mensah. 2014. E-waste disposal effects on the aquatic environment: Accra, Ghana. Reviews of Environmental Contamination and Toxicology 229: 19-34.

Jasanoff, S. 2015. Future imperfect: science, technology, and the imaginations of modernity. In S. Jasanoff and SH. Kim (eds.). Dreamscapes of modernity: sociotechnical imaginaries and the fabrication of power. Chicago: University of Chicago Press. Pp. 1-33. 
Karikari, A.Y., K.A. Asante and C.A. Biney. 2006. Water quality characteristics at the estuary of Korle Lagoon in Ghana. West African Journal of Applied Ecology 10(1): 10-18.

Kaza, S., L. Yao, P. Bhada-Tata and F. Van Woerden. 2018. What a waste 2.0: a global snapshot of solid waste management to 2050. Washington, DC: World Bank.

Khan, S.A., 2016. E-products, E-waste and the Basel Convention: regulatory challenges and impossibilities of international environmental law. Review of European, Comparative and International Environmental Law 25(2): 248-260.

Konadu-Agyemang, K. 2000. The best of times and the worst of times: structural adjustment programs and uneven development in Africa: the case of Ghana. The Professional Geographer 52(3): 469-483.

Lepawsky, J. 2018. Reassembling rubbish: worlding electronic waste. MIT Press.

Lepawsky, J. G. Akese, M. Billah, C. Conolly and C. McNabb. 2016. Composing urban orders from rubbish electronics: cityness and the site multiple. International Journal of Urban and Regional Research 39(2): 185199.

Lepawsky, J. and C. Mather. 2011. From beginnings and endings to boundaries and edges: rethinking circulation and exchange through electronic waste. Area 43(3): 242-249.

Lepawsky, J. 2014. The changing geography of global trade in electronic discards: time to rethink the e-waste problem. The Geographical Journal 10: 1-13.

Lepawsky, J. 2015. Are we living in a post-Basel world? Area 47(1): 7-15.

Lepawsky, J. and C. McNabb. 2010. Mapping flows of electronic waste. The Canadian Geographer 54: 177-195.

Liboiron, M. 2015. Redefining pollution and action: the matter of plastics. Journal of Material Culture 21(1): 87110.

Little, P.C. 2016. On electronic pyropolitics and pure earth friction in Agbogbloshie. Toxic News Nov. 8.

Little, P.C. and C. Lucier. 2017. Global electronic waste, third party certification standards, and resisting the undoing of environmental justice politics. Human Organization 76(3): 204-214.

Little, P.C. 2019. Bodies, toxins, and e-waste labour interventions in Ghana: toward a toxic postcolonial corporality. Revista de Antropología Iberoamericana 14(1): 51-71.

Little, P.C. Forthcoming. Burning matters: global e-waste and pyropolitics in postcolonial Ghana. Oxford: Oxford University Press.

Nnorom, I.C. and O. Osibanjo. 2008. Overview of electronic waste (e-waste) management practices and legislations, and their poor applications in the developing countries. Resources, Conservation and Recycling 52(6): 843858.

Onuoha, D. 2016. Economies of waste: rethinking waste along the Korle Lagoon. The Journal for Undergraduate Ethnography. Accessed at https://undergraduateethnography.org/files/Onuoha-JUE161.pdf

Ottaviani, J. 2015. E-waste Republic. European Journalism Centre document on Al Jazeera.

PBS. 2009. FRONTLINE/World Ghana: digital dumping ground. PBS documentary, USA. I Accessed at http://www.pbs.org/frontlineworld/stories/ghana804

Pellow, D. 2008. Landlords and lodgers: socio-spatial organization in an Accra community. Chicago: University of Chicago Press.

Ntiamoa-Baidu, Y. 1991. Seasonal changes in the importance of coastal wetlands in Ghana for wading birds. Biological Conservation 57: 139-158.

Oteng-Ababio, M. and R. Grant. 2018. Ideological traces in Ghana's urban plans: how do traces get worked out in the Agbogbloshie, Accra? Habitat International 83: 1-10.

Pickren, G. 2014. Political ecologies of electronic waste: uncertainty and legitimacy in the governance of e-waste geographies. Environment and Planning A 46(1): 26-45.

Quayson, A. 2014. Oxford Street, Accra: city life and the itineraries of transnationalism. Durham: Duke University Press. 
Roberts, J. 2010. Korle and the mosquito: histories and memories of the anti malaria campaign in Accra, 1942-1945. The Journal of African History 51: 343-365.

Schluep, M., T. Terekhova, A. Manhart, E. Müller, D. Rochat and O. Osibanjo. 2012. Where are WEEE in Africa? Findings from the Basel Convention E-waste Africa Programme. Secretariat of the Basel Convention (SBC).

Squire J. 2018. Mitigating the Korle Lagoon ecological pollution problem in Accra, Ghana, through a framework for urban management of the environment. In Swatuk L. and C. Cash (eds.). Water, energy, food and people across the Global South. Palgrave Macmillan. Pp. 117-134.

Steinberg, P.E. 2013. Of other seas: metaphors and materialities in maritime regions. Atlantic Studies 10(2): 156-169.

Steinberg, P.E. and K. Peters. 2015. Wet ontologies, fluid spaces: giving depth to volume through oceanic thinking. Environment and Planning D: Society and Space 33: 247-264.

Washington Post. 2015. Making a living in the toxic world of discarded electronics. The Washington Post. Accessed at https://www.washingtonpost.com/news/in-sight/wp/2015/04/15/the-children-who-make-a-living-in-thetoxic-world-of-discarded-electronics

Winder, G.M. and R. Le Heron. 2017. Assembling a Blue Economy moment? Geographic engagement with globalizing biological-economic relations in multi-use marine environments. Dialogues in Human Geography 7(1): 3-26.

Wittsiepe, J., J.N. Fobil, H. Till, G.D. Burchard, M. Wilhelm and T. Feldt. 2015. Levels of polychlorinated dibenzop-dioxins, dibenzofurans (PCDD/Fs) and biphenyls (PCBs) in blood of informal e-waste recycling workers from Agbogbloshie, Ghana, and controls. Environment International 79: 65-73.

World Bank. 2018. Implementation completion and results report IDA 50970 on a credit in the amount of SDR19.4 million (US\$30 million equivalent) to the Republic of Ghana for the Ghana - PPP Project. Report No: ICR00004638. November 30. Finance, Competitiveness and Innovation Global Practice, Africa Region. Washington DC: World Bank. Accessed at http://documents.worldbank.org/curated/en/159951546546576136/pdf/icr00004638-12282018636818041814084888.pdf

Yeboah, I. 2000. Structural adjustment and emerging urban form in Accra, Ghana. Africa Today 47(2): 61-89. 